PAEDAGOGIA CHRISTIANA

$1 / 25$ (2010) - ISSN 1505-6872

Adam Lepa*
Łódź-Warszawa

\title{
Obszary „dialogu przez media”
}

Głośno postulowany dialog międzyludzki zrodził się w ubiegłym stuleciu jako spontaniczna reakcja na wydarzenia, które nadały owemu stuleciu piętno wieku tragicznego. Były to: straszliwe wojny światowe i okrutne totalitaryzmy, zorganizowane ludobójstwa, obozy koncentracyjne i gułagi, bezwzględny terroryzm i najbardziej wyszukane formy poniżania godności człowieka. W przekonaniu społeczności światowej dialog wydawał się wtedy najlepszym narzędziem do uśmierzenia różnorakich konfliktów - na tle ideologicznym, gospodarczym, politycznym czy militarnym. Aktywnym i skutecznym promotorem w tej dziedzinie był Kościół katolicki. Jako pierwszy dostrzegał on w środkach masowego komunikowania ogromny potencjał, który powinien być wykorzystany w budowaniu powszechnego dialogu między ludźmi i między narodami.

Celem artykułu jest ukazanie szerokich możliwości, jakimi mogą dysponować media w działaniach na rzecz dialogu. Przy czym, obok mediów „tradycyjnych”, takich jak prasa, fotografia, radio i telewizja, uwzględnione zostaną również nowe, jak na przykład wideo, Internet czy multimedia.

Podjęty problem rozpatrywany jest w kontekście zmian cywilizacyjnych, jakie ogarnęły w ostatnich dziesięcioleciach świat mediów. W następstwie tego powstały nowe zjawiska, które w literaturze przedmiotu i w publicystyce otrzymały różnorakie określenia: „szok mediów”, „cywilizacja obrazu”, ,rewolucja medialna” czy po prostu „nowa epoka mediów”'.

* Bp dr Adam Lepa, wykładowca w Instytucie Edukacji Medialnej i Dziennikarstwa Uniwersytetu Kardynała Stefana Wyszyńskiego w Warszawie oraz w Wyższym Seminarium Duchownym w Łodzi.

${ }^{1}$ M. Boullet, Le choc des médias, Tournai 1985; M. D’Ambra, Le nuove tecniche di comunicazione, Milano 1995; M. Lepori (red.), Multimedialità. Epoca nuova di vita, Rimini 
Artykuł składa się z trzech części. Pierwsza przybliża zjawisko dialogiczności jako głównej cechy mediów. Druga część pokazuje na czym polega międzyludzki „dialog przez media” i jakie on zajmuje obszary. Część trzecia zawiera główne wskazania na temat wychowania do „dialogu przez media".

Należy podkreślić, że problematyka „dialogu przez media” nie doczekała się pełnego opracowania i odpowiednich badań. Można więc żywić nadzieję, że artykuł niniejszy mógłby być wykorzystany jako przyczynek do dalszych poszukiwań w tej ważnej dziedzinie wiedzy o mediach.

\section{Dialogiczność mediów}

Podkreśla się dziś, że media z natury swojej są dialogiczne. Wynika to $\mathrm{z}$ ich misji. Są wszak pośrednikami między nadawcą a odbiorcą. Przy czym tę cechę mediów najbardziej jednoznacznie wyraża termin „dialogiczność”. Precyzyjniej, niż na przykład „dialogalność” czy „dialogowość”. Wyraźnie bowiem podkreśla fakt, że jest to wewnętrzna cecha mediów.

\section{Charakterystyka dialogiczności}

Dialogiczność mediów polega na stałej ich tendencji do podejmowania typowych dla dialogu relacji z ich odbiorcami. Dialogiczność ujawniają wszystkie media, począwszy od radia i telewizji, poprzez prasę i Internet, a skończywszy na plakacie, ulotce czy folderze.

Funkcjonowanie w mediach dialogu $\mathrm{z}$ ich odbiorcami wyjaśnia się za pomocą mechanizmu przesłania, jakie emitowana treść zawiera i jest percypowana przez odbiorców mediów (czytelników, słuchaczy, widzów). Przesłanie to wyrażone w słowie, obrazie i dźwięku skłania ich do odpowiedniego ustosunkowania się wobec jego treści i do wyrażenia właściwych reakcji (emocjonalnych, w dziedzinie myśli, skojarzeniowych i słownych). Obcowanie więc z treściami, które rozpowszechniają media, przeradza się w dialog o różnym nasileniu i czasie trwania. Ten dialog ma to do siebie, że może doprowadzić do związania się danej osoby z konkretnym medium masowym, a nawet do uzależnienia się od niego ${ }^{2}$.

1996; T. Goban-Klas, Cywilizacja medialna, Warszawa 2005; V. Flusser, La Civilisation des médias, Dijon 2006; M. Lister (i in.) (red.), New Media: a critical Introduction, New York 2009.

2 A. Lepa, Mass media - uzależnienie czy rozwój?, „Tygiel Kultury” 10-12 (2004), s. 127-131; por. Ph. Le Guern (red.), Les cultes médiatiques, Rennes 2002. 
Wprawdzie media skierowane są do masowej publiczności, jednak przesyłana treść jest tak skonstruowana, że odbiorca jest przekonany, iż stał się jednym z ich ważnych adresatów. Ponadto, daje znać o sobie, przede wszystkim w korzystaniu z telewizji, zjawisko interakcji paraspołecznej ${ }^{3}$. Powstaje ona w następstwie braku bezpośredniego kontaktu z widzem. Dlatego w telewizji podejmuje się takie działania, które mają wytworzyć w odbiorcy poczucie zażyłości, a nawet pewnej intymności wobec osoby prowadzącej program. Widz ma odnosić wrażenie, że jest partnerem telewizji, a ona oferuje mu swoją wierną przyjaźń. Środkiem w osiaganiu tego efektu jest empatia, którą reżyseruje się tak przekonująco, że odbiorca telewizji nie ma najmniejszych wątpliwości co do jej wiarygodności. Interakcja paraspołeczna praktykowana $\mathrm{w}$ telewizji jest dialogiem pozornym. Z czasem może się stać wyrafinowaną postacią manipulacji.

W refleksji nad dialogiem podkreśla się twórczą rolę języka. Podjęte przez Johna L. Austina badania dowiodły, że język niesie w sobie dużą siłę oddziaływania na partnera ${ }^{4}$. Związek ten wyraża znane powiedzenie „mówić znaczy oddziaływać" (Quand dire, c'est faire). Podkreśla się znaczenie praktyczne tej prawidłowości: począwszy od refleksji nad dialogiem, poprzez dydaktykę filologiczną, a skończywszy na badaniach z zakresu psycholingwistyki, psychologii społecznej czy antropologii ${ }^{5}$. Zasadę tę należy odnieść w jakiejś mierze również do mediów w warstwie ich interaktywności. Wszak w każdej postaci interakcji zachodzą wpływy wzajemne, co pogłębia siłę oddziaływania na partnerów dialogu. Przy czym kontakt bezpośredni staje się głębszy i bardziej skuteczny niż ten, który realizowany jest za pośrednictwem mediów.

\section{Formy dialogiczności}

Istnieje duża różnorodność form dialogiczności mediów. Występują one w dwóch podstawowych grupach: w obrębie mediów drukowanych i mediów elektronicznych. Przy czym powstają nowe formy tych drugich, gdyż istnieje nieustanny rozwój techniki i wciąż daje znać o sobie fakt, iż człowiek jest istotą komunikującą ${ }^{6}$.

${ }^{3}$ W. Cwalina, Interakcje paraspołeczne między widzami a osobami prowadzacymi programy telewizyjne, w: P. Francuz (red.), Psychologiczne aspekty odbioru telewizji, Lublin 1999, s. 53-78.

${ }^{4}$ J. L. Austin, How to do Things with Words, Harvard 1962.

${ }^{5}$ C. Kerbrat-Orecchioni, Les actes de langage dans le discours, Paris 2008, s. 157-162.

${ }^{6}$ R. Ghglione, L'homme communiquant, Paris 1986. 
Dialogiczność mediów drukowanych charakteryzuje się specyfiką, którą wyznaczają takie czynniki jak brak ulotności, typowej dla mediów elektronicznych (radia, telewizji, Internetu) i związany z tym kontakt wydłużony. Istnieje ponadto większa swoboda selektywnego wyboru książek oraz tytułów prasy, a w niej gatunków dziennikarskich, oraz, co jest istotne w każdej formie dialogu - praktyczna możliwość wzajemnej wymiany interesujących tekstów.

O interaktywności można mówić również w odniesieniu do mediów drukowanych. Ma ona miejsce wtedy, gdy ich odbiorca (czytelnik) podejmuje dialog z autorami tekstów za pośrednictwem telefonu, poczty elektronicznej czy tradycyjnego listu. Szczególną rolę spełnia lektura dialogów literackich. Sprawia ona, że czytelnik współuczestniczy w opisywanym wydarzeniu. Autor tekstu literackiego poprzez współobecność czytelnika czyni go współuczestnikiem dialogu? Z Znamiona dialogu z autorem tekstu wykazuje również „metoda ołówka”, gdy czytelnik na marginesie czytanej książki lub artykułu nanosi swoje uwagi i w ten sposób „dyskutuje” z autorem.

Dialogiczność mediów w Polsce wkroczyła na nowe tory po 1989 r. Przełom ustrojowy i podejmowane transformacje pozwoliły na wprowadzenie w polskich mediach interaktywności. Polega ona na jednoczesnym kontakcie osobowym uczestników komunikacji. Przed 1989 r. komunikowanie masowe można było realizować wyłącznie w jednym kierunku, tzn. od nadawcy do odbiorcy (nadawca $\rightarrow$ odbiorca). Obecne media elektroniczne coraz częściej stosują dwukierunkowe przesyłanie informacji przy jednoczesnym zaangażowaniu zarówno nadawcy, jak i odbiorcy (nadawca $\leftrightarrows$ odbiorca). W związku z tym stwierdza się w polskich mediach elektronicznych rosnącą wciąż popularność programów opartych na dialogu (dyskusja, wywiad, talk-show itp.).

Wpływ na dialog międzyludzki wywierają różnorakie programy w radio i telewizji. Te zwłaszcza, które oparte są na wypowiedziach wzajemnych w studio, w dyskusji na określony temat oraz w przygotowanej wcześniej konwersacji z elementami narracji ${ }^{9}$. Programy tego typu mogą się przyczynić do uformowania w odbiorcach postawy dialogu. Jest to tym bardziej możliwe, że w mediach elektronicznych istnieje duża różnorodność realizowania kontaktów międzyludzkich. Świadczą o tym choćby ich terminy kluczowe (wypowiedź, wymiana myśli, wtrącenie, zapytanie-odpowiedź itp.), które ujawnia analiza dyskursu międzyludzkiego ${ }^{10}$.

7 A. Skudrzykowa, Język mówiony w dialogach literackich, w: Z. Kurzowa, W. Śliwiński (red.), Wspótczesna polszczyzna mówiona, Kraków 1994, s. 123-130.

${ }^{8}$ A. Zwoliński, Stowo w relacjach społecznych, Kraków 2003, s. 44 n.

${ }^{9}$ C. Kerbrat-Orecchioni, La conversation, Paris 1996.

${ }^{10}$ D. Maingueneau, Les termes clés de l'analise du discours, Paris 1996. 
Istnieje powszechna opinia, iż mediami, które wykazują największą interaktywność, są czasopisma elektroniczne.

\section{Stanowisko Kościoła}

Do dalszych rozważań niezbędne jest przypomnienie stanowiska Kościoła wobec dialogu, a w szczególności w odniesieniu do dialogu realizowanego przez media i dzięki mediom. Należy podkreślić, że Kościół ze względu na swoją naturę dialogiczną upatruje w mediach sprzymierzeńca ${ }^{11}$. Widać to najwyraźniej w realizowaniu misji ewangelizacyjnej. Dlatego mówi się dziś o dialogu Kościoła ze światem mediów.

W pierwszej fazie dialogu Kościoła z mediami dominują z jego strony ostrożność i czujność z pewną dozą niepokoju. Po II wojnie światowej w miejsce pewnej nieufności i rezerwy wobec mediów Kościół przyjmuje postawę podziwu wobec nich, a nawet fascynacji.

Sobór Watykański II wytyczył kolejny okres dialogu Kościoła z mediami. Postawa urzeczenia przeobraża się teraz w obdarowanie mediów wielkim kredytem zaufania oraz optymizmem co do realizowania ich misji w świecie. Na tę zmianę wpłynęły dwie okoliczności: duch Soboru Watykańskiego II i fakt, że Kościół dopracował się teologii mediów. Przejawem nowej postawy Kościoła wobec mediów stała się Instrukcja duszpasterska Stolicy Apostolskiej Communio et progressio (1971) (Zjednoczenie i postęp), opracowana na polecenie Soboru.

Dziś można stwierdzić, że Kościół już zdołał się „oswoić” z mediami, patrzy na nie życzliwie, ale stawia im wymagania. Jednocześnie czyni starania, aby posiąść sztukę wychowania do mediów, dzięki czemu wchodzi w dialog z rzeszą rodziców, nauczycieli i wychowawców. We wspomnianej instrukcji Kościół podkreślił, że w mediach „znajduje echo i podnietę codzienna wymiana myśli między ludźmi i w ten sposób rodzi się i utwierdza publiczny dialog całego społeczeństwa" (CP 19). Dlatego papież Jan Paweł II w przemówieniu do biskupów polskich w Rzymie w 1998 r. mówił, że „Kościół widzi w mediach przede wszystkim drzemiący olbrzymi potencjał ewangelizacyjny i szuka sposobów ich wykorzystania w działalności apostolskiej”. Przypomniał jednocześnie, że ,właściwym celem i zadaniem społecznych środków przekazu jest służba prawdzie i jej obrona”.

${ }^{11}$ F. F. Plude, Interactive Communication in the Church, w: P. Granfield (red.), The Church and Communication, Kansas City 1994, s. 179-195; A. Lepa, Kościót a media, w: S. Fel, J. Kupny (red.), Katolicka nauka społeczna, Katowice 2007, s. 241-258. Por. H. Skorowski, Dialog, w: B. Szlachta (red.), Stownik społeczny, Kraków 2004, s. 133-138. 


\section{Międzyludzki ,dialog przez media”}

Przedmiotem refleksji w artykule jest „dialog przez media”. Zastosowane określenie stanowi skrót myślowy. Chodzi tu o dialog, który media prowadzą ze swoimi odbiorcami, albo dialog, w którym one jedynie uczestniczą, a ktoś inny go podjął i nim kieruje. Tym drugim podmiotem dialogu może być ośrodek władzy (parlament, rząd, prezydent państwa), ugrupowanie polityczne czy Kościół. Jak widać, media mogą być podmiotem dialogu albo jego partnerem. Mogą też być jednocześnie zarówno podmiotem, jak i partnerem dialogu. W każdym jednak przypadku są one środkiem dialogu. Przy czym media wtedy najbardziej sprzyjają rozwojowi dialogu, gdy są miejscem jego realizacji.

\section{Pojęcie i rodzaje dialogu}

Wyjaśnienia wymaga sam termin „dialog”. Na ogół przyjmuje się, że dialog jest rozmową, w której uczestniczą przynajmniej dwie osoby, prowadzącą do wzajemnego zrozumienia poglądów, stanowisk, postaw, ocen i motywacji, a także do pogłębienia prawdy i podjęcia współdziałania. Tak rozumiany dialog jest synonimem rozmowy. Z kolei dłuższa wypowiedź jednej osoby jest monologiem ${ }^{12}$.

Są różne rodzaje dialogu. Wyróżnia się dialog indywidualny i społeczny, a następnie dialog wewnątrzkościelny, dialog ekumeniczny i dialog międzyreligijny. Ponadto jest dialog międzynarodowy i dialog prowadzony w obrębie konkretnego narodu. Wyróżnia się też dialog autentyczny i dialog pozorny czy fałszywy. Ten drugi ma miejsce w niektórych postaciach programów telewizyjnych. Należy też rozróżniać między dialogiem bezpośrednim i dialogiem pośrednim. Ten pierwszy jest realizowany dzięki spotkaniu typu „twarzą w twarz” (face à face). Natomiast dialog pośredni jest prowadzony za pośrednictwem środków społecznego przekazu, a wśród nich za pomocą mediów masowych. Tu trzeba wyjaśnić, że nie wszystkie „środki społecznego przekazu" są mediami masowymi. Nie są nimi zasadniczo telefon, jak również Internet, gdy informacja za ich pośrednictwem kierowana jest do konkretnego adresata. $Z$ kolei blog staje się medium masowym, gdy treści przesyłane za jego pośrednictwem adresowane są do szeroko pojętej publiczności.

${ }^{12}$ R. Łukaszyk, Dialog, w: Encyklopedia katolicka, t. 3, Lublin 1979, kol. 1258-1262; F. Mazière, L'analise du discours, Paris 2005. 


\section{Stare i nowe obszary „dialogu przez media”}

Poszerza się wciąż płaszczyzna „dialogu przez media”. Spowodowane to jest jakościowym i ilościowym rozwojem mediów, ostrą konkurencja, a w szczególności powstawaniem nowych technologii w dziedzinie komunikowania masowego ${ }^{13}$.

W tym punkcie refleksji przedstawione będą dwie grupy mediów: 1. grupa mediów starych („tradycyjnych”) oraz 2. grupa nowych mediów, która wyłoniła się w latach osiemdziesiątych XX wieku. Nieliczni przeciwnicy takiego podziału podkreślają, że w rozwoju mediów istnieje ciagłość i wzajemna zależność w funkcjonowaniu, a ponadto ostatecznie, niezależnie od podziału, wszystkie media (stare i nowe) znajdują się w gestii starych właścicieli i dysponentów.

1. Prezentację „starych” mediów ogranicza się w niniejszym tekście do tzw. mediów podstawowych. Jest to podyktowane faktem, iż właśnie te media dały początek wszystkim pozostałym, także „nowym mediom”. Są to: prasa, film, radio i telewizja. Siła tych mediów i zakres oddziaływania, a także wysoki stopień popularności w ich odbiorze sprawiaja, że spełniają one istotną rolę w kulturze masowej. Samo funkcjonowanie tych mediów jest inspirujące w poszukiwaniach nad ich dalszym rozwojem ${ }^{14}$.

Choć nowe media, w szczególności Internet, stają się dziś coraz bardziej popularne, to jednak media „tradycyjne” nadal są przedmiotem uwagi olbrzymiej części społeczeństwa. Nadal bowiem utrzymuje się wielka liczba użytkowników prasy, radia i telewizji. Wbrew sceptycznym prognozom, również kino nie przegrało z telewizją, a aparat fotograficzny z kamerą wideo. Ponadto, niektóre właściwości mediów podstawowych ułatwiają w dużej mierze podejmowanie dialogu z tymi mediami, a pod ich wpływem także dialogu z innymi ludźmi. Oto przykładowo podane właściwości mediów podstawowych.

P r a s a jest najbardziej pedagogicznym medium masowym. Sposób odbioru prowadzi bowiem do jej skutecznego oddziaływania na postawy i opinie czytelników ${ }^{15}$. Tym bardziej, że z natury swojej prasa zapewnia wydłużoną stałość kontaktów czytelnika z publikowanymi treściami oraz do-

${ }^{13}$ A. Stefanizzi, Le nuove technologie di comunicazione, Roma 1983; J. Guyot, Les techniques audiovisuelles, Paris 1997.

${ }^{14}$ A. Renaud, Gui Debord: de la télévision au multimédia, „Cité” 2 (1997), s. 2, 7-18; B. Darras, Multimédia et éducation à l'image, „Mediation et Information” 11 (2000), s. 143-156 ; M. Agnola, R. Le Champion, La télévision sur Internet, Paris 2003.

${ }^{15}$ A. Lepa, Pedagogia prasy, „Mass Media” 1 (1989), s. 15-17; P. Albert, La presse, Paris 1996. 
wolność w powtarzaniu tych kontaktów. Sprawia to, że pogłębione zostaje rozumienie odbieranych tekstów i jest więcej czasu na refleksję nad nimi. Prasa należy do najbardziej dostępnych mediów.

Wspomniano już o możliwościach prowadzenia dialogu na linii redakcja-czytelnicy. Odbywa się to za pośrednictwem telefonu, poczty internetowej czy zwykłego listu. Jak wynika z obserwacji, sztuki dialogu uczą wywiady prasowe. Zadawanie pytań przez dziennikarza i uzyskiwanie odpowiedzi pokazują jak należy formułować problemy oraz jak powinno się zachować logikę myśli i stosować dociekliwość w stosunku do podejmowanych zagadnień. Wywiady prowadzone przez profesjonalistów uczą również czytelnika kultury słowa i piękna mowy polskiej, co w sztuce dialogu ma niebagatelne znaczenie.

Obcowanie z prasą ambitną przygotowuje czytelnika do podejmowania dojrzałego dialogu z ludźmi. Zgodnie ze znaną tezą Marshalla McLuhana, prasa ma to do siebie, że pogłębia w czytelniku myślenie. Okoliczność ta sprawia, że prowadzenie dialogu z ludźmi staje się łatwiejsze, zapewnia mu osobistą satysfakcję i rozwija go intelektualnie.

Również film, wbrew pozorom, jest dialogotwórczy. Głównie dlatego, że ukazuje konkretne problemy, jakimi żyje człowiek, stawiając przed nim różnego rodzaju dylematy i propozycje wyboru. To wywołuje wymianę myśli i ocen. Film uczy też sztuki prowadzenia dialogu. Przestrzega przed dialogiem jałowym i wiodącym na manowce. Był tym medium, które jako pierwsze inicjowało w kulturze masowej kult gwiazd ${ }^{16}$. W tym nurcie kształtował w swoich młodych odbiorcach model dialogu, tym bardziej godny naśladowania, że promowany przez znane gwiazdy filmu, estrady i sportu. Podkreśla się dziś, że jednym z kluczy wyjaśniających tajemnicę popularności kina jest fakt, iż oferuje ono człowiekowi ten sposób komunikowania, który przyczynia się do zbudowania wspólnoty wśród odbiorców obrazu filmowego i tworzy swoistą ikonosferę, która ułatwia widzowi koncentrowanie się na wartościach i stereotypach promowanych $\mathrm{w}$ filmie oraz sprzyja prowadzonemu na ten temat dialogowi ${ }^{17}$. Do dialogu skłaniają też różnorakie problemy moralne, które właśnie w filmie pokazywane są z dużą wyrazistością ${ }^{18}$.

Dzięki swojej naturze $\mathrm{r}$ a d i o nadaje dialogiczności wymiar szczególny. Bowiem jego foniczność „odkrywa” w człowieku tę warstwę, dzięki której nazywa się go homo audiens. W kulturze przedpiśmiennej słowo mó-

${ }^{16}$ K. Żygulski, Socjologia filmu, Warszawa 1966, s. 111-120.

${ }^{17}$ R. W. Kluszczyński, Typy komunikowania w sztuce filmowej, „Przekazy i Opinie” (1986), s. 117-128.

${ }^{18}$ J. L. Duhourq, Przejawy i interpretacja zła moralnego we współczesnej sztuce filmowej, „Concilium” 6-10 (1970), s. 46-53. 
wione było głównym środkiem komunikowania międzyludzkiego. Później kultura druku zdominowała tę sferę i w znacznym stopniu uszczupliła „audytywność" człowieka ${ }^{19}$. Dialog prezentowany w radio jest bardzo bogaty. Wszak duża część programów oparta jest na rozmowie. Należy podkreślić, że obecnie radio najpełniej realizuje postulat interaktywności. Jeżeli zaś uwzględni się fakt, że słowo mówione ma większy wpływ na psychikę słuchacza niż słowo „czytane oczami”, wtedy zrozumie się znaczenie audycji radiowych w przyswajaniu przez odbiorcę radia sztuki prowadzenia dialogu. W języku mówionym dają znać o sobie takie czynniki, jak odpowiednia tonacja, zabarwienie uczuciowe czy dobór słów, które najlepiej oddają intencję autora. Okoliczności te zapewne zmniejszają wpływy ulotności, która towarzyszy radiu ${ }^{20}$. Biorąc to pod uwagę, można powiedzieć, że radio jako medium masowe może stać się szkołą dialogu. Przekazuje słuchaczom jego dobre wzorce, zachęca do podejmowania ambitnych rozmów i inspiruje do wypowiadania myśli twórczych i niebanalnych. W ujęciu McLuhana, radio najbardziej mobilizuje do wspólnego działania. Oznacza to, że jego wpływ w stopniu szczególnym prowokuje słuchaczy do dialogu międzyludzkiego. Wszak wspólne działanie z innymi ludźmi zasadniczo idzie w parze z realizowanym dialogiem.

Wspomniano wcześniej, że t e 1 e w i z j a oferuje widzowi także dialog pozorny. Niemniej jednak, oprócz możliwości podejmowania kontaktów interaktywnych z widzami, zdolna jest pokazać im również „dialog na żywo", a w nim ludzi uczestniczących w sytuacjach ekstremalnych, na przykład w katastrofie (lotniczej, kolejowej), a nawet w kataklizmie (trzęsienie ziemi, powódź). Jedynie telewizja zdolna jest to przeprowadzić (radio tylko w warstwie fonicznej) i w tym tkwi jej główny walor, gdyż w ten sposób ujawnia ona pewną dozę swoistej dydaktyki, przez co uczestniczyć może w kształtowaniu postawy dialogu u swoich odbiorców ${ }^{21}$. Jeszcze wyraźniej widać to w sytuacji, gdy uczestników spotkania, znajdujących się w różnych miejscach, łączy telemost.

O telewizji McLuhan mówił, że ona godzi z rzeczywistością przedstawianą na małym ekranie. Oznacza to, że jej wpływ ubiernia odbiorców i przyczynia się do ukształtowania u nich postawy konformistycznej wobec prezentowanych treści. Jednocześnie zaś telewizja, dostarczając człowiekowi widowiska, zaspokaja w nim ważne potrzeby psychiczne, na przykład odkrywa i zarazem niweluje element obcości. Sprawy, które są pozornie

${ }^{19}$ E. Kofin, Komunikacja audytywna, „Przekazy i Opinie” 1 (1982), s. 5-39.

${ }^{20}$ W. Legowicz, Radio - ulotność stowa?, Warszawa 1986, s. 12-16.

${ }^{21}$ H. Newcomb (red.), The Television. The Critical View, New York 1994; L. Porcher, Télévision, culture, éducation, Paris 1994; E. Menduni, La televisione, Bologna 1998. 
niezrozumiałe, stają się dzięki niej czytelne, a nawet oczywiste i wtedy ma miejsce zjawisko „oswajania nieznanego" ${ }^{22}$. Biorąc jednak pod uwagę fakt, że telewizja jest w Polsce najbardziej popularnym medium, należy wnosić, że wywiera niemały wpływ na postawy odbiorców, również na postawę dialogu. Przy czym w refleksji nad tym wpływem należy uwzględnić udział tzw. czynników pośredniczących (np. postaw, cech psychicznych, interakcji czy wychowania). Od nich w dużym stopniu uzależniona jest skuteczność oddziaływania telewizji. W tej dziedzinie liczy się także wzmacniający wpływ mediów. Bowiem z badań wynika, że na przykład telewizja zasadniczo wzmacnia istniejące już opinie, poglądy, a nawet postawy swoich odbiorców ${ }^{23}$. A zatem wzmacniać może również aktualny stosunek odbiorców do dialogu. Stanowi więc szansę dla rozwoju i pogłębienia dialogu międzyludzkiego.

2. Gdy w latach siedemdziesiątych ukazały się na rynku pierwsze komputery osobiste, pojawiła się telefonia komórkowa i zbudowano fundamenty Internetu, ogłoszono narodziny rewolucji technologii informacyjnych ${ }^{24}$. W następstwie upowszechnienia technik komputerowych i technologii przekodowywania transmisji i komunikatów analogowych na cyfrowe pojawiają się „,nowe media”. Dziś z perspektywy minionego czasu widać wyraźnie, jak dalece komputerowa rewolucja medialna przekształciła poszczególne etapy komunikacji masowej. Ma to miejsce zarówno w gromadzeniu danych i ich przechowywaniu, jak i w przetwarzaniu i dystrybucji. Ten wpływ obją także wszystkie media - począwszy od książki i prasy, poprzez film i radio - a skończywszy na telewizji.

Powstaje zjawisko hipertekstu w cyberprzestrzeni, który realizuje się w środowisku komputerowym. Jest to tekst „,nielinearny”, odczytywany wyłącznie na internetowym ekranie. Hipertekst jest strukturą specyficzną dla gier komputerowych czy bazy danych. Stał się głównym impulsem dla prac nad rozwojem multimediów, których cechami charakterystycznymi są multiemisja (różnorakie przekazy z jednego źródła albo nadawanie przekazów z wielu źródeł) oraz interaktywność ${ }^{25}$. Multimedia funkcjonują w oparciu

${ }^{22}$ I. Hermann, Czym jest utwór telewizyjny?, „Przekazy i Opinie” 4 (1979), s. 36-42; J. Wyskiel, Telewizja, czyli nie spetnione marzenia, w: M. Czerwiński (red.), Telewizja i spoteczeństwo, Warszawa 1980, s. 123-130.

${ }^{23}$ J. T. Klapper, The Effects of Mass Media, New York 1960, s. 15-52.

${ }^{24}$ R. Wallstein, Les vidéocommunications, Paris 1992 ; F. Mascolo, L. Fiorella, G. Michelone, Internet. L'informazione senza frontiera, Milano 1997; L. Groff, Rewolucja informacyjna: globalne trendy restrukturyzacyjne, wizje i decyzje, w: L. W. Zacher (red.), Problemy społeczeństwa informacyjnego, Warszawa 1997, s. 15-21; P. Flichy, L'imaginaire d'Internet, Paris 2001; T. Goban-Klas, Media i komunikowanie masowe, Warszawa 2006, s. 286-309.

${ }^{25}$ M. Alberganti, Le multimédia. La révolution au bout des doigts, Paris 1996. 
o dwa kanały nadawania: akustyczny i wizualny (pismo, obraz ruchomy i statyczny). Znajdują szerokie zastosowanie w edukacji i w rozrywce ${ }^{26}$.

Zdaniem Waltera J. Onga, rozwój multimediów prowadzi do tzw. wtórnej oralności. Ma ona przyczynić się do stopniowego zaniknięcia technologicznego środowiska mediów, aby zapewnić uczestnikom tego rodzaju komunikacji poczucie kontaktu bezpośredniego. Ong, który twierdził, że kultura oralna jest kultura pierwotną, nazywał „oralnością wtórną” współczesną kulturę wysokiej technologii. Dowodził, że ,liczne kultury i podkultury, nawet związane z wysoką technologią, zachowują niemało zróżnicowanych nastawień właściwych oralności pierwotnej" ${ }^{27}$. Tego rodzaju ocena nowych mediów jest ważną przesłanką w refleksji nad ich zaangażowaniem w dialogu międzyludzkim.

Wbrew pesymistycznym prognozom, nowe media mogą służyć dialogowi w stopniu nie mniejszym niż media stare, a więc te, które pojawiły się w obiegu nie później niż telewizja „tradycyjna"28. Dziś należy powiedzieć, że nowe media stanowią dużą szansę dla komunikacji międzyludzkiej, a tym samym dla dialogu. Wskazują na to liczne leksykony poświęcone problematyce tych mediów ${ }^{29}$. Oto ważniejsze ,atuty" nowych mediów w nurcie budowania dialogu.

Dzięki funkcjonowaniu nowych mediów uruchamiana jest odpowiednia interakcja, tzn. nie bezpośrednia, „twarzą w twarz”, lecz „pośrednia-zmediatyzowana”, którą można nazywać ,quasi interakcją". Interaktywność danego medium może ją przeobrazić w postać dialogu.

Zarówno Internet, jak i Intranet (wewnątrzfirmowa sieć komputerowa) umożliwiają i usprawniają komunikację międzyludzką w skali świata i w skali konkretnego przedsiębiorstwa. Ułatwiają też dostęp do potrzebnych danych, co z kolei mobilizuje innych do współdziałania i dialogu.

W odniesieniu do Internetu wymieńmy przykładowo te jego usługi, które pozwalają podjąć i udoskonalić interakcję medialną, służącą dialogowi międzyludzkiemu:

- Przesyłanie plików między komputerami (FTP - File Transfer Protocol) jako forma komunikacji.

- Wymiana opinii, informacji i uczestniczenie w dyskusji.

- Poczta elektroniczna (e-mail), która stała się główną siłą napędową w ekspansji Internetu.

${ }^{26}$ J. Colombain, La cyberculture, Toulouse 1997, s. 28-37; B. Siemieniecki, Multimedia i hipermedia w edukacji, w: tenże (red.), Edukacja medialna, Toruń 2002, s. 245-281.

${ }^{27}$ W. J. Ong, Oralność i piśmienność. Stowo poddane technologii, Lublin 1992, s. 32.

${ }^{28}$ F. Balle, Médias et societés, Paris 2003, s. 151-243; J. Chapman, Comparative Media History, Cambridge 2005, s. 207-265.

${ }^{29}$ Zob. np. A. Giovenali, Dizionario dei nuovi media, Milano 1997. 
- Skype (Skype Technologies SA), komunikator internetowy, służący do rozmów głosowych w sieci z możliwością widzenia się z rozmówcą (kamera).

Kontaktom międzyludzkim o charakterze dialogu służy coraz wydatniej telefon komórkowy z aparaturą umożliwiającą fotografowanie i filmowanie oraz przesyłanie uzyskanego materiału. $\mathrm{Z}$ telefonem komórkowym wiązana jest również usługa przesyłania krótkich informacji (SMS - Short Messaqe Service). Dalszym etapem rozwoju SMS jest MMS, mający charakter multimedialny (MMS - Multi Media Service), tzn. umożliwiający przesyłanie wraz z krótkimi wiadomościami również fotografii, dźwięków i animacji.

\section{Zakłócenia „dialogu przez media”}

W świecie mediów, zwłaszcza nowych mediów, dają znać o sobie symptomy zmian pozytywnych i korzystnych dla rozwoju ich użytkowników. Jednym z nich jest przesunięcie punktu ciężkości z przeżywania przyjemności i relaksu na poznawanie nowych treści i komunikację międzyludzką. Jednocześnie stwierdza się rosnącą interaktywność oraz indywidualizację kontaktów z możliwością programowania. Podkreśla się przy tym, że nowe media to przede wszystkim nowe techniki informacyjno-komunikacyjne. Dzięki nim następuje wzrost w różnorodności treści, w dialogowości kontaktu, aktywności nadawcy i odbiorcy. Ważną wskazówką jest też podkreślanie w definicji „społeczeństwa sieciowego", że choć w funkcjonujących w nim mediach treścią jest informacja, to jednak istotę stanowi komunikacja ${ }^{30}$. Zmniejsza się też przedział czasowy między nadaniem informacji a jej odbiorem.

Są jednak zjawiska, które zakłócają dialog międzyludzki prowadzony przez media, uniemożliwiają jego podjęcie czy wręcz marginalizują go. Widać to wyraźnie na przykładzie Internetu ${ }^{31}$. Stanowi szansę dla ludzi poszukujących wiedzy i autentycznych kontaktów z innymi. Jednakże zawiera również treści zachęcające do działań przeciwko społeczeństwu. Szerzone są hasła nawołujące do nienawiści na tle różnic wynikających z przynależności etnicznej, narodowej i wyznaniowej. Treściami, które burzą prawidłowe relacje międzyludzkie, są w Internecie ,seksstrony”32. Odwiedzający je wydali w 2001 roku na ten cel miliard dolarów. Z badań wynika, że materiałem najbardziej poszukiwanym w Internecie są treści związane z seksem, a por-

\footnotetext{
${ }^{30}$ J. Mikułowski-Pomorski, Komunikacja a interkomunikacja, w: L. W. Zacher (red.), dz. cyt., s. 2-9.

${ }^{31}$ S. Juszczyk, Globalna sieć komputerowa - INTERNET - w edukacji, w: B. Siemieniecki (red.), Edukacja medialna, s. 283-335; por. L. Floridi, Internet, Milano 1997.

${ }^{32}$ S. Juszczyk, dz. cyt., s. 327-329.
} 
nografia przynosi właścicielom tego rodzaju witryn gigantyczne zyski. Jeżeli przyjąć, że pornografia fałszuje obraz człowieka, to nie ulega wątpliwości, że jej obecność w świecie mediów uniemożliwia podjęcie autentycznego i trwałego dialogu międzyludzkiego ${ }^{33}$. Przykładem mogą być perwersyjne dialogi, prowadzone $\mathrm{w}$ kontakcie $\mathrm{z}$ internetową pornografią, również $\mathrm{z}$ dziećmi.

Innym zjawiskiem, które niweczy w mediach podejmowanie dialogu, jest współczesna mitologia. Mit jest poglądem, który nieistniejącym wydarzeniom i zjawiskom nadaje pozory niewzruszonej prawdy ${ }^{34}$. Dialog, który z definicji ma być wspólnym poszukiwaniem prawdy, nie może się stać ,dialogiem przez media”, jeżeli uwikłany jest w funkcjonujące w nich mity. Dobitnym tego przykładem są dziś dyskusje podejmowane w polskich mediach na temat stosunku papieża Piusa XII do Holokaustu. Mit „postawy obojętności” tego papieża, zbudowany (jak wskazują wiarygodne dokumenty) przez komunistyczne służby specjalne, nadal daje znać o sobie w wypowiedziach wielu Polaków, co w dużym stopniu utrudnia twórczy i spokojny dialog.

Przeszkodą, z którą należy się liczyć, rozpatrując „dialog przez media”, jest cała sfera działań manipulatorskich, podejmowanych przez me$\mathrm{dia}^{35}$. W telewizji manipulacja przyjmuje formy, które nie budzą niepokoju, a nawet są niedostrzegane. Przykładowo, wymienić można takie z nich, jak banalizacja wartości, wspomniane wcześniej manipulatorskie wykorzystanie interakcji paraspołecznej czy zatrucie informacyjne, które polega na tym, że w sposób celowy i obmyślany tak się przedstawia w telewizji sprawy bardzo ważne, jakby one były mało istotne albo nic nie znaczyły. I odwrotnie ${ }^{36}$.

Wymienione niepokoje i zastrzeżenia nie podważają szans, jakie zapewniają dialogowi międzyludzkiemu media - zarówno te tradycyjne, jak i media nowe. Natomiast skłaniają do refleksji nad wychowaniem do mediów - aby było ono również przygotowaniem do udziału w dialogu autentycznym i twórczym.

\section{Wychowanie do „dialogu przez media”}

Dotychczasowa refleksja prowadzi do wniosku, że media stwarzają nowe możliwości w podejmowaniu i pogłębieniu twórczego dialogu. Są one szansą dla samych siebie i dla społeczeństwa, w którym funkcjonują. Aby mogły wypełnić swoją misję na tym polu, należy odpowiednio przygotować

33 J. Bajda, Zafatszowanie obrazu człowieka: pornografia, „Ethos” 4 (1993), s. 72-91.

${ }^{34}$ A. Lepa, Mity i obrazy, Łódź 1999, s. 6-15.

${ }^{35}$ B. Siemieniecki (red.), Manipulacja - Media - Edukacja, Toruń 2007.

${ }^{36}$ F. Jost, Le culte du banal, Paris 2007; A. Lepa, Telewizja $w$ rodzinie, Częstochowa 2008. 
ich użytkowników. Dlatego w programie wychowania do mediów powinna się znaleźć problematyka dialogu, a w niej temat umiejętności dostrzegania „dialogu przez media” i sztuki twórczego udziału w nim. W zachodnim piśmiennictwie temat ten jest wyraźnie postulowany ${ }^{37}$. Jednocześnie podkreśla się, że w erze rzeczywistości wirtualnej podejmowany dialog prowadzić może do trwałych więzi społecznych ${ }^{38}$.

\section{Podstawy wychowania do mediów}

W świetle dokumentów Stolicy Apostolskiej, wychowanie do mediów ma swoją specyfikę. Jej kanon stanowią następujące zasady: 1. Przekazanie podstawowej wiedzy o mediach (o ich naturze i kierunkach wpływu); 2. Ukształtowanie odpowiednich postaw (przede wszystkim postawy krytycznej wobec mediów i postawy ich selektywnego odbioru); 3. Uformowanie sumienia wrażliwego na prawdę, dobro i piękno (inspirującego do pozytywnego oddziaływania na media). Jak widać, Kościół w swojej pedagogii nie ogranicza się jedynie do dydaktyki mediów, lecz zaleca wychowanie do mediów w ścisłym słowa znaczeniu. Dlatego trzonem tego wychowania jest kształtowanie postaw i formowanie sumienia.

Równolegle z kształtowaniem wymienionych postaw wychowawca powinien pomóc młodemu człowiekowi w uwolnieniu z postaw negatywnych, jeżeli stały się one rezultatem niewłaściwego odbioru mediów. Najważniejsze z nich to: postawa uległości wobec oddziaływań mediów, postawa uzależnienia się od mediów i postawa makiawelizmu. Dwie ostatnie są szczególnie groźne dla rozwoju osobowości. Uzależnienie od mediów skutkuje negatywnie w sferze relacji społecznych, a także w wypełnianiu obowiązków podstawowych (rodzinnych, zawodowych, szkolnych, religijnych). W dużym stopniu postawa ta blokuje dialog z innymi osobami. Z kolei postawa makiawelizmu polega na stałej tendencji w jednostce do manipulowania drugim człowiekiem. Również i ta postawa utrudnia, a nawet niweczy dialog międzyludzki.

Należy podkreślić, że przedmiotem wychowania do mediów powinny być nie tylko dzieci szkolne. Jan Paweł II w cytowanym wcześniej przemówieniu do biskupów polskich przypomniał, że „istnieje pilna potrzeba właściwego wychowania całego społeczeństwa, szczególnie młodzieży, do umiejętnego i dojrzałego korzystania ze środków przekazu".

\footnotetext{
${ }^{37}$ Zob. np. E. Schiavina, Media, società - mondo, formazione, Milano 1995; J. Gonnnet, Éducation et médias, Paris 1999.

${ }^{38}$ G. Dubey, Le lien social à l'ère du virtuel, Paris 2001; R. Bautier, De la rhétorique à la communication, Grenoble 2004.
} 
Na koniec należy wspomnieć, że na temat wychowania do mediów istnieje już w Polsce bogata literatura ${ }^{39}$. Gdy zaś chodzi o współpracę z nowymi mediami na polu twórczego dialogu, edukacja medialna nie może się ograniczyć do przekazania wiedzy na temat ich struktury i funkcjonowania czy technik posługiwania się nimi. Jednym z głównych zadań pedagogów w tej dziedzinie powinno być nauczenie języka nowych mediów, który jest niezastąpionym kluczem do zrozumienia ich natury, tworzonych nowych kodów, stylów zachowania i tego, co nazywa się dziś technokulturą. Jak zapewnia Lev Manovich, nowe media zrealizują nadzieję zobaczenia na nowo świata i człowieka ${ }^{40}$. Należy oczekiwać, że poprzez twórczy dialog przyczynią się także do zbudowania wielkiej i solidarnej wspólnoty ludzkiej.

\section{Ksztaltowanie postawy dialogu}

Wychowanie do mediów powinno prowadzić do udziału w „dialogu przez media". W literaturze przedmiotu podkreśla się, że niejako z natury swojej media zdolne są do kształtowania w swoich odbiorcach postawy dialogu albo przynajmniej przybliżają wartość dialogu ${ }^{41}$. Dzięki interaktywności mediów elektronicznych ich odbiorca może się znaleźć w orbicie komunikowania uczestniczącego i stać się partnerem dialogu, którego podmiotem jest radio lub telewizja. Również do tego zadania należy przygotować uczestników edukacji medialnej. Tym bardziej, że w takim dialogu istnieje możliwość wywierania pozytywnego wpływu na dane medium w formie korekty albo w postaci propozycji programowej.

Postawa dialogu polega na budowaniu przez jednostkę względnie trwałych relacji o charakterze partnerskim, opartych na wzajemnym zrozumieniu i szacunku, i prowadzących do aktywnego współdziałania ${ }^{42}$. W postawie tej zaangażowane są przede wszystkim intelekt i wola. Widać to wyraźnie w triadzie czynności podstawowych, jakie należy podejmować w dialogu: umieć mówić, umieć powiedzieć, umieć zakomunikować ${ }^{43}$. W tym zestawieniu rozróżnia się między „mówieniem w ogóle” a „powiedzeniem” drugiej osobie czegoś, co przykuje jej uwagę, zastanowi i stanie się „zakomunikowaniem siebie samego".

${ }^{39}$ Zob. np. A. Lepa, Pedagogika mass mediów, Łódź 1998; W. Strykowski (red.), Media a edukacja, Poznań 2000; M. Sokołowski (red.), Wyzwania pedagogiki medialnej, Olsztyn 2001; B. Siemieniecki (red.), Pedagogika medialna, Warszawa 2007.

${ }^{40}$ L. Manovich, Język nowych mediów, Warszawa 2006.

${ }^{41}$ J. M. Cotteret, La magie du discours. Précis de rhétorique audiovisuelle, Paris 2000.

${ }^{42}$ A. Lepa, Media a postawy, Łódź 2003, s. 64-69.

${ }^{43}$ J. Gérard-Naef, Savoir parler. Savoir dire. Savoir communiquer, Paris 1987. 
W kształtowaniu postawy dialogu, która jest główną płaszczyzną w wychowaniu do „dialogu przez media”, należy uwzględniać wskazania sformułowane przez specjalistów w tej dziedzinie ${ }^{44}$. Oto ważniejsze z nich:

- w postawie dialogu kładzie się nacisk na to, co ludzi łączy z jednoczesną świadomością istniejących różnic;

- dialog wymaga sztuki kompromisu niezbędnej w stosunkach międzyludzkich;

- w postawie dialogu dominuje relacja „ty” - ,ja”, wykluczająca jakąkolwiek dyktaturę i egoistyczny monolog;

- postawę dialogu wspierają inne postawy, na przykład postawa cierpliwości i wyrozumiałości - nadają one dialogowi trwałość;

- w postawie dialogu niezbędna jest empatia, która każe patrzeć na partnera dialogu z jego punktu widzenia; sensowność realizowanego dialogu pogłębia świadomość, że może on prowadzić do braterskiej wspólnoty.

Podjęty w artykule temat znajduje się w kręgu zagadnień, które przypominają o najważniejszych zadaniach stojących przed mediami. Ich realizacja uzależniona jest od osobistego zaangażowania ludzi mediów oraz od aktywności ich adresatów. Nie trzeba dowodzić, że w tym kontekście rola nauczycieli i wychowawców jest zawsze najważniejsza. Natomiast być człowiekiem dialogu i innych formować do „dialogu przez media” staje się dziś wyjątkowo szlachetną i ambitną misją pedagoga.

\section{The areas of 'dialogue via media' (Summary)}

The present paper is concerned with the dialogicity of media, in particular its nature and forms. Close consideration of the issue points out a phenomenon labelled 'dialogue via media'. The phenomenon stems from the cooperation between the sender and the addressee. It is stressed that the most favourable conditions for the development of this type of dialogue are created by the media which constitute a site of the dialogue rather than merely its means or tool.

The domain of media is viewed in terms of their usefulness in the joint effort of creating dialogue. Two types of media are taken into account: (1) 'old' (traditional) media such as the press, film, radio, television, poster, leaflet, and brochure, and (2)

${ }^{44}$ J. Tarnowski, Próby dialogu z młodymi, Katowice 1983; R. L. Howe, Il miracolo del dialogo, Roma 1996; M. Śnieżyński, Zarys dydaktyki dialogu, Kraków 1997; A. Skowronek, Ku pedagogii dialogu, „Paedagogia Christiana” 1 (1997), s. 63-72; M. Poty, L'illusion de communiquer, Paris 2004. 
'new' media which emerged after television was invented. The latter result from the revolution in information technology and embrace the Internet, multimedia (with their multibroadcasting and interactivity) and a mobile telephone, which enables photographing, filming and sending thus obtained material.

The reflection on the nature of media, including the 'new' ones, leads to the conclusion that they provide an opportunity to continuously enter into 'dialogue via media'. If suitably prepared, media users can make use of this opportunity profitably, which makes teachers face an important and urgent task. 
